\section{J OURNAL OF}

French and Francophone Philosophy
REVUE DE LA

philosophie française et de langue française

\title{
The Cinematic Bergson: From Virtual Image to Actual Gesture
}

John Ó Maoilearca

Journal of French and Francophone Philosophy - Revue de la philosophie française et de langue française, Vol XXIV, No 2 (2016) 203-220.

\author{
Vol XXIV, No 2 (2016) \\ ISSN 1936-6280 (print) \\ ISSN 2155-1162 (online) \\ DOI $10.5195 /$ jffp. 2016.777 \\ www.jffp.org
}

\section{(c)) EY-NC-ND}

This work is licensed under a Creative Commons Attribution-Noncommercial-No Derivative Works 3.0 United States License.

\section{ULIS D-Sunt}

This journal is operated by the University Library System of the University of Pittsburgh as part of its D-Scribe Digital Publishing Program, and is co-sponsored by the University of Pittsburgh Press 


\title{
The Cinematic Bergson
}

\section{From Virtual Image to Actual Gesture}

\author{
John Ó Maoilearca \\ Kingston University, London
}

According to Gilles Deleuze "cinema is Bergsonian."1 Despite the fact that Henri Bergson critiques the cinematographic mechanism in his magnum opus Creative Evolution ${ }^{2}$ (on account of its movement being one applied to still images rather than being immanent to them), Deleuze correctly realized how central the moving image nonetheless was to Bergson's philosophy. Yet this was already clear in Bergson's own testimonies: "When I first saw the cinematograph I realized it could offer something new to philosophy. Indeed we could almost say that cinema is a model of consciousness itself. Going to the cinema turns out to be a philosophical experience."3 If Bergson's relationship with the cinematic apparatus is ambivalent, (being a model of consciousness, but only in how it distorts the real), it remains to be seen in what manner his affirmative stance towards film should be understood. In his positive account, Deleuze emphasizes the virtual image from Bergson's earlier work, Matter and Memory, in order to show how movement is indeed immanent to the image, but only in virtue of its incorporeality. Such "virtualism" has been criticized elsewhere for its unBergsonian tenets. ${ }^{4}$ In what follows we will show how the cinematic body offers another way of rendering cinema Bergsonian. This more actualist Bergsonism is not pursued in order to be more faithful to Bergson, however, but to show how his ideas dovetail with modern corporeal, gestural readings of the film image. When Dominique Chateau writes in Cinéma et philosophie that Bergson was the first major philosopher to take cinema as a model for philosophy, this is not only a historical thesis: his ideas remain pertinent to a range of contemporary approaches in film theory and place further weight on role of the body, not only for the experience of the spectator but also in the very nature of the moving image. ${ }^{5}$ 


\section{Something Infinitely Simple}

Amongst Jean Renoir's various maxims concerning the creative process, probably the most renowned touches on a lack at the heart of such creativity: "But, you know, everyone really only makes one film in his life, and then breaks it up into fragments and makes it again." 6 Yet such repetition within creation need not lead us to doubt the possibility of novelty. This becomes clear when we look at another, cognate observation from Renoir's fellow Frenchman, Henri Bergson, only this time regarding philosophy. Discussing the "single point" that each philosopher makes throughout his or her whole career, he writes:

In this point is something simple, infinitely simple, so extraordinarily simple that the philosopher has never succeeded in saying it. And that is why he went on talking all his life. He could not formulate what he had in mind without feeling himself obliged to correct his formula, then to correct his correction: thus, from theory to theory, correcting when he thought he was completing, what he has accomplished, by a complication which provoked more complication, by developments heaped upon developments, has been to convey with an increasing approximation the simplicity of his original intuition. All the complexity of his doctrine, which would go on ad infinitum, is therefore only the incommensurability between his simple intuition and the means at his disposal for expressing it. What is this intuition? ${ }^{7}$

Coming from Bergson's essay, "Philosophical Intuition," the first answer to his question - what is intuition? - will arrive in the form of the philosophical "image," a "mediating" image that is "almost matter in that it still allows itself to be seen, and almost mind in that it no longer allows itself to be touched." 8 Yet it is not, he assures us, to be confused with the virtual images discussed in his earlier work Matter and Memory, but something far more actual, more embodied (and yet still not a spatial, fixed, body): It is, Bergson writes,

A receding and vanishing image, which haunts, unperceived perhaps, the mind of the philosopher, which follows him like his shadow through the ins and outs of his thought and which, if it is not the intuition itself, approaches it much more closely than the conceptual expression, of necessity symbolical, to which the intuition must have recourse in order to furnish "explanation." Let us look closely at this shadow: by doing so we shall divine the attitude of the body which projects it. And if we try to imitate this attitude, or better still to assume it ourselves, we shall see as far as it is possible what the philosopher saw. ${ }^{9}$

Deleuze, we know, made much of the virtual images of Matter and Memory in his two Cinema books, transforming a psycho-meta-physical thesis into an 
ontological one (thereby disregarding Bergson's own anti-ontological stance) while also distorting Bergson's negative view of the cinematic apparatus (in Creative Evolution) into a positive view of cinema editing. In this essay, we will instead be pursuing this "attitude of the body" that projects the vanishing but singular image of philosophical intuition. And we will do so through an analogy with the idea of "one" (image or idea) that underpins a film. This will be an attempt, therefore, to generate or project a film of intuition-to assume (or suggest) the (film) image of (philosophical) intuition (rather than simply one more philosophy of film). ${ }^{10}$ After all, even in Matter and Memory, the image is described ardently as something that is not a picture ("to picture is not to remember"), and the brain is portrayed as an organ of mime. The brain does not represent (an idea, or a picture); rather, it performs its images through its own equivalent of an actor's "gestures and attitudes." 11 It is this performed, bodily cinema that we will examine, both through what Bergson has to say about gesture, and through a gestural concept enacted by a film, to be precise, Lars von Trier's The Five Obstructions (2003). ${ }^{12}$

This will also bring us back to the idea of what it is that is being remade, both by directors and philosophers, in Renoir's "one film" and Bergson's singular "vanishing image." The Five Obstructions is comprised of five remakes of an original work by another film-maker, Jørgen Leth. Leth, a mentor of von Trier, is instructed by von Trier to remake five sequences from his own 1967 short film, The Perfect Human (a pseudo-anthropological study of human behaviour). Each remake comes with an obstruction or "creative constraint." The constraints are as follows: 1 . that it be remade with no shot longer than 12 frames; 2 . that it be remade in the most miserable place on earth; 3 . that it be remade with no constraint at all (a form of metaobstruction of total freedom); 4 . that it be remade as a cartoon (the definition of a non-film for both von Trier and Leth); and finally, 5. that von Trier makes the fifth remake, though it must be both credited to and narrated by Leth.

As such, one way of reading The Five Obstructions is precisely as an enactment of Renoir's adage-that each film-maker only makes one film, again and again-with von Trier forcing Leth to recompose The Perfect Human repeatedly following certain constraints. Such forms of experimentation in film are not unique, however. In 1998 Gus Van Sant directed a shot-by-shot remake of Alfred Hitchcock's 1960 classic horror film, Psycho. While the new film was in colour, rather than the original's black and white, and was set in a contemporary era with a new cast, it otherwise retained nearly all of the first film's audio-visual structureincluding Bernard Hermann's score. ${ }^{13}$ Indeed, such was its fidelity to the 1960 film that some critics dubbed it a (rather pointless) "duplicate" rather than a remake.14 A duplicate like this, presumably, would lie somewhere between a mere re-mastered print of the original and a true remake. But if a 
remake is to be more than a duplicate, then what exactly is being remade (if it is not an audio-visual structure)? In answer to why Van Sant's audiovisual replica of the structure of Psycho was deemed such a failure we will propose that the sheer repetition of such structures is never invention. Rather, what is remade-but with novelty - is never a fixed image or sound, a propositional state or story. And this is the (Bergsonian) conjecture we will pursue: that what is remade (by philosopher or director) is not a picture but a posture-a bodily stance or "attitude." It is this gestural recreation that allows novelty and repetition to coexist.

\section{Bergsonian Re-orientations}

One basis for Bergson's re-orientation (from picturing to posturing) in Matter and Memory and beyond can be gleaned from the description of intuition offered in his 1903 essay, "Introduction to Metaphysics." Here, Bergson outlines the famous contrast between creative intuition and the "readymade" concepts of "analysis": "To try a concept on an object is to ask of the object what we have to do with it, what it can do for us. To label an object with a concept is to tell in precise terms the kind of action or attitude the object is to suggest to us." 15 Bergson's corporealist stance is already indicated in this use of terms such as "attitude" and it is ability to "suggest": attitudine, "fitness, posture;" and suggerere, "bring from below," from "gesture" or gerere, to "bear, wield, perform." And both are linked to Bergson's most renowned formulation of intuition that comes in the same essay: thinking in duration means "to reverse the normal direction of the workings of thought." 16 Few philosophers have argued anything so heretical as we find in Bergson's approach to metaphysics, that is, a radical reversal of what we think metaphysics (and philosophy) to be and how we think it operates (in an "anti-Kantian" metaphysics of immanence, as Quentin Meillassoux describes Bergson's method). ${ }^{17}$ More than this, it leads us to a redirection of where thinking is supposed to take place: thinking changes source and direction, passing from things to concepts, and not from concepts to things. Bergson's idea is not that we merely change the direction of our thought about things (whatever that might mean), but that metaphysical thinking somehow starts with the object too, at least as an orientation, posture, or attitude. This is his call to re-orient or reverse our stance: the inversion of the work of the mind is not intellectualist, but behavioural in attitude.

At an even more most abstract level, this postural aspect of Bergson's thought engages with the theory of images in Matter and Memory. Let us recall the basics of the imagology in its first chapter where what we perceive is only what interests us (and our bodies) at any moment:

To the degree that my horizon widens, the images which surround me seem to be painted upon a more uniform background and become to me more indifferent. The more I narrow this horizon, the 
more the objects which it circumscribes space themselves out distinctly according to the greater or lesser ease with which my body can touch and move them. They send back [renvoient, "return"], then, to my body, as would a mirror, its eventual influence; they take rank in an order corresponding to the growing or decreasing powers of my body. The objects which surround my body reflect its possible action upon them. ${ }^{18}$

There is a "background" that re-turns to my body only what interests it, so that even "distance" itself takes on an axiological form, representing "above all, the measure in which surrounding bodies are insured, in some way, against the immediate action of my body." 19 My body is simply "an object", but one capable of performing a "new action" upon surrounding objects, and this ability to act anew is what marks out its "privileged position" in regard to other, background objects. Hence, to undo what the body instigates, to reverse this "narrow" attitude, is to look again in detail (in higher-definition) and in close-up at this background: it requires a reversal of orientation.

Indeed, in Matter and Memory even memory, apparently the most virtual element of Bergson's thought, is tied to bodily stance:

Whenever we are trying to recover a recollection, to call up some period of our history, we become conscious of an act sui generis by which we detach ourselves from the present in order to replace ourselves, first, in the past in general, then, in a certain region of the past-a work of adjustment, something like the focusing of a camera. But our recollection still remains virtual; we simply prepare ourselves to receive it by adopting the appropriate attitude..$^{20}$

If this seems to go too far-especially given Bergson's purportedly disembodied "spiritualist" tendencies - then the following description of education from the introduction to The Creative Mind may help to confirm this revision of his work. Here he argues that, to understand a text, a student

Must fall into step with him [the author] by adopting his gestures, his attitudes, his gait, by which I mean learning to read the text aloud with the proper intonation and inflection. The intelligence will later add shades of meaning. Before intellection properly socalled, there is the perception of structure and movement; there is, on the page one reads, punctuation and rhythm. Now it is in indicating this structure and rhythm, in taking into consideration the temporal relations between the various sentences of the paragraph and the various parts of each sentence, in following uninterruptedly the crescendo of thought and feeling to the point musically indicated as the culminating point that the art of diction consists. [...] One knows, one understands only what one can in some measure reinvent. ${ }^{21}$ 
Reinvention is not the repetition of fixed structures but "structure and rhythm" - movement or gesture. In the footnote that follows this passage, Bergson goes even further in this gestural comprehension of comprehension, arguing that "rhythm roughly outlines the meaning of the sentence truly written, that it can give us direct communication with the writer's thought before study of the words has given them color and shading." 22 In one lecture at the Collège de France on Descartes' Discours de la Méthode, he tells us that he took some pages of the text as an example "to show how the comings and goings of thought, each in a particular direction, pass from the mind of Descartes to our own solely by the effect of the rhythm as indicated by the punctuation, and especially as brought out by reading it aloud correctly." 23 This footnote then refers the reader to Bergson's 1912 lecture "The Soul and the Body" where thinking is vectorised in a clearly behaviourist manner, albeit also being internalised as a tendency, "nascent" and "performed in the brain":

Consider thinking itself; you will find directions rather than states, and you will see that thinking is essentially a continual and continuous change of inward direction, incessantly tending to translate itself by changes of outward direction, I mean by actions and gestures capable of outlining in space and of expressing metaphorically, as it were, the comings and goings of the mind. Of these movements, sketched out or even simply prepared, we are most often unaware, because we have no interest in knowing them; but we have to notice them when we try to seize hold of our thought in order to grasp it all living and make it pass, still living, into the soul of another. The words may then have been well chosen, but they will not convey the whole of what we wish to make them say if we do not succeed by the rhythm, by the punctuation, by the relative lengths of the sentences and part of the sentences, by a particular dancing of the sentence, in making the reader's mind, continually guided by a series of nascent movements, describe a curve of thought and feeling analogous to that we ourselves described. [...] The rhythm speech has here, then, no other object than that of choosing the rhythm of the thought: and what can the rhythm of the thought be but the rhythm of the scarcely conscious nascent movements which accompany it? These movements, by which thought continually tends to externalize itself in actions, are clearly prepared and, as it were, performed in the brain. ${ }^{24}$

Here we have a kind of micro-behaviourism of the brain as well as the macro-behaviourism of bodies in relation-one that would short-cut the traditional disputes between "central state" materialists and logical behaviourists by rendering behaviour neurological while also upgrading cerebral motor-mechanisms to something more than just mechanical 
movements. If the brain does "control" behaviour, it is because it too is behaviour.

\section{Gestural Cinema}

Of course, explicitly behavioural analyses in cinema theory are not unusual either, though few can be as radical as that of Giorgio Agamben, for whom it is gesture, rather than the image, which is the fundamental filmic property. His short essay, "The Six Most Beautiful Minutes in the History of Cinema", for example, discusses a sequence from Orson Welles's unfinished Don Quixote in terms of gesture:

Sancho Panza enters a cinema in a provincial city. He is looking for Don Quixote and finds him sitting off to the side, staring at the screen. The theater is almost full; the balcony - which is a sort of giant terrace - is packed with raucous children. After several unsuccessful attempts to reach Don Quixote, Sancho reluctantly sits down in one of the lower seats, next to a little girl (Dulcinea?), who offers him a lollipop. The screening has begun; it is a costume film: on the screen, knights in armor are riding along. Suddenly, a woman appears; she is in danger. Don Quixote abruptly rises, unsheaths his sword, rushes toward the screen, and, with several lunges, begins to shred the cloth. The woman and the knights are still visible on the screen, but the black slash opened by Don Quixote's sword grows ever larger, implacably devouring the images. In the end, nothing is left of the screen, and only the wooden structure supporting it remains visible. ${ }^{25}$

Quixote's gesture destroys the cinema image, and, likewise, Agamben claims that gesture is the quintessential cinematic element, replacing the photograph as its fundamental unit:

The mythical rigidity of the image has been broken and that here, properly speaking, there are no images but only gestures. Every image, in fact, is animated by an antinomic polarity: on the one hand, images are the reification and obliteration of a gesture (it is the imago as death mask or as symbol); on the other hand, they preserve the dynamis intact. 26

Agamben's analyses of cinema indicate a nostalgia for "the homeland of gesture." 27 But they are also a political and ethical call for a future cinema that reconfigures the relationship between image and gesture. For him, the moving image as gesture has the power to liberate the cinematic from the last traces of a static image.

Despite his focus upon gesture, we will not follow Agamben any further here even if, in one respect, we stay true to his line (which itself 
follows Foucault) that what we call "gesture" is only "what remains unexpressed in each expressive act" and "the exhibition of a mediality: it is the process of making a means visible as such." 28 Indeed, one of Bergson's most notorious demands for philosophy is that it should seek a means to know the Real without any "expression, translation or symbolic representation." 29 And for Bergson, intuitive "metaphysics is that means. Metaphysics, therefore, is the science which claims to dispense with symbols." 30 And yet we know that when Bergson describes a metaphysics that would dispense with symbols, it is really a question of what type of symbolism is at stake, fluid or fixed, suggestive or direct, bespoke or ready-made, and not the symbolic tout court. A philosophy-without-symbols is really a philosophy-without-standardsymbols, therefore, and is practiced without fixed representations (be they linguistic, conceptual, or photographic). It begins, he says, with images that gesture toward (suggest) an intuition. Images direct us towards intuitions, they do not stand for (represent) intuitions.

\section{Unconstrained Style:}

\section{Behaviourism in The Five Obstructions}

Earlier, I described Von Trier's The Five Obstructions as a work whose very form explores a number of issues concerning aesthetic creativity and generative constraint. The third of the five constraints was also a meta-level one, involving no constraint at all-complete artistic freedom. For a filmmaker in the realist tradition like Leth, however, this was a definite imposition. The perversity arises because Leth initially asks for an alternative constraint whereby von Tier would provide a new set of obstructions for him to endure: as he says, "I prefer you to make the decisions." Yet, precisely because that would be Leth's preference, von Trier decrees that it is Leth who must make all the decisions in absolute freedom for this third remake. So, why is such total freedom an imposition for Leth (beyond the usual psychoanalytic/existential responses concerning the intolerable burden of personal responsibility)? It is simply because von Trier shares with Leth the idea that constraints are crucial for creativity in filmmaking, such that imposing a free-style film on his former teacher can only be-as Mette Hjort puts it-"a straightforward negation of Leth's characteristic approach." 31

We must note here that Leth's model of optical film-realism involves patience, that is, a certain kind of passivity: "I normally find places and then isolate something I want to examine. That's the method. And then I frame it very precisely and wait for the right moment. I believe very strongly in waiting and observing." 32 Leth allows the moment to be captured to present itself-to let the randomness of the Real take its course. Admittedly, it is he who selects the "decisive moment" to record (to borrow one of CartierBresson's terms), but its emergence is spontaneous. Let us say that it belongs 
to the Real (or Real Time, as Bergson would call it). Ordering Leth to make any film he wishes in the third obstruction is actually an imposition of sorts: less the burden of responsibility than the burden of creativity. Leth's natural preference is to let the Real offer up the "concrete instants" that he will passively record, rather than that he conduct all affairs. Forcing all of the decision-making process onto Leth actually removes his artistic freedom, oddly enough. Naturally, Leth is free to escape from his freedom, in this third film at least, by reverting to his usual long-take realist aesthetic. And yet, this is not what he does. Instead, he offers up a highly stylised, rather formal piece, using split screens, cryptic monologues, and quite clichéd "arthouse" imagery (a mysterious man and woman, sexual encounters in expensive hotel rooms, a sense of political or criminal intrigue, slow-moving limousines, clandestine meetings in rainy, desolate locations, and so on).

Earlier, I alluded to the pseudo-anthropological approach in The Perfect Human in its original form. The narration of the third remake (in English), compounds this impression even further:

Here's the man. Here he is. What's he want?

Here's the woman. Here she is. What does she want?

Here's a man. We don't know him. I don't know what to say about him. We love that he is special, unreasonable. A distant look, a loss of soul, a distant look.

I would like to know something more about him. I can see that he is here, and that he works. I have seen him smoke a cigarette. I didn't see him write. Is he good at describing death? Does he think about fucking? He is alone, preparing himself. He goes out and takes care of things. He's the perfect man.

In this and other sequences the question as to what the man is thinking is reiterated, but never answered. All we are given are external details, visuals of movement-of smoking, of shaving, of waiting. Alongside this unanswered enquiry comes the peculiar mannerism of this version, with a certain "type" of art-house cinema being replicated throughout. Paramount in this, however, is the acting role of the male protagonist. Leth casts Patrick Bauchau to play "the man" (Claus Nissen's role in the original) almost entirely because of his presence and style. Murray Smith remarks on this as follows:

The casting of Patrick Bauchau in \#3: Brussels, for example, [was] inspired by Leth's admiration for his performance as the protagonist of Eric Rohmer's La collectionneuse. Intriguingly, Rohmer's film was, like The Perfect Human, released in 1967; it as if Leth has chosen a better-known counterpart to Claus Nissen - an equally handsome actor from the same generation, both born in 1938 - in order to stress the effects of time and experience on the 
model-like "perfection" of the figures in his original film (Leth notes the importance of Bauchau's "well-bruised" quality to his casting in \#3: Brussels). ${ }^{33}$

Nonetheless, it is not as if Bauchau is given much to do by Leth in this film, for he mostly poses in rooms, has little dialogue and even less interaction with other actors. He is there because of his "look." Leth is obviously delighted with his casting, stating that he is "...really pleased with him. He looks great. [...] He is well [...] well bruised as a person. He has experience of life. He has lived a life. His story is fantastic." 34 Bauchau, then, stands for a certain type and remakes the Claus Nissen protagonist through a distinctive acting style, almost bordering on non-acting: he is a man who "takes care of things" just by looking like such a man. Indeed, of all six films, the original and the third versions of The Perfect Human place the most emphasis on acting style (as opposed to editing in One, location in Two, animation in Four, and performativity in Five). ${ }^{35}$ And it is Murray Smith, once more, who finds the right idea on this front when describing the original The Perfect Human:

The Perfect Human is an enigmatic, spare narrative film, depicting a man and a woman engaged in various generic activities - eating, dancing, undressing, shaving-mostly in isolation from one another. [...] The setting of the film is abstract in the extreme: the performers are afforded certain minimal props (a razor, a bed, a dining table) but the space behind them is so overexposed as to lead the eye into a white void. The man and the woman are beautiful, young, chic; much of the time they are doing little more than striking poses in the featureless zone that they occupy. ${ }^{36}$

It is possible to read The Five Obstructions as a reflection on difference and repetition in film-making, with von Trier forcing Leth to recompose The Perfect Human repeatedly following certain constraints. But the obstructions to each remake nonetheless ensure a creative reproduction, rather than a faithful replica. This has been accounted for partly through the use of constant stylistic innovation. As von Trier writes of his own work: "You can become so good at producing things that they become nauseatingly boring to look at. That might have happened had I continued to make the same film again and again, as some people do." 37 Von Trier is known for not repeating himself, at least stylistically - switching genres and aesthetics (realism, magic realism, documentary, theatricality, abstraction) at every opportunity. Yet, von Trier insists on a partial repetition in each task given to Leth, albeit that the added obstructions guarantee a certain creativity in style. Mette Hjort comments on this, saying that "the commitment [to renewing styles] throughout, it transpires, is to a form of self-provocation that involves abandoning the cinematic techniques as they are mastered in favour of new challenges." 38 Hence, we should interpret the qualification above, "at least stylistically", in such a way that the issue of style becomes a highly 
significant approach. As Smith also writes, "In The Five Obstructions the game of style is narrativised; the variations in style have an overt motivation in the narrative contest recounted by the film. Even so, the variations are not motivated in the traditional manner as apt stylistic expressions of theme."39 In the opening obstruction, set in Cuba, a certain behavioural attitude is also assumed. Adopting the same pseudo-anthropological pose as its original, this The Perfect Human also asks questions such as "What is the perfect human thinking? Is he thinking about happiness? Death? Love?" And yet the answers eventually provided to these and other questions often appear to be pseudo-answers, at least for those who are looking for sufficient reasons. Paisley Livingston describes the situation thus:

The response to the question: "Why does he move this way?" is a comical flaunting of Trier's injunction to answer the questions raised by the narrator of The Perfect Human; the proposed answer ("Because women like it") does not really answer the question, while seeming to do so in a blunt way; all the other questions remain willfully unanswered in the remake, which reinforces the thought that Leth has cleverly slipped past this obstruction. ${ }^{40}$

However, I would want respond to Livingston that questions such as "what is he thinking?" or those concerning the character's motivations are indeed answered, only through external behaviour or style of movement. The film takes an externalist approach to questions of putatively inner motivation. It is a filmic behavourism. Hjort adds to this point about acting and style by referring to Arthur Danto's claim, in The Transfiguration of the Commonplace, that "style is a gift" (it cannot be directed), and expresses individual "ways of seeing the world.'" 41 Danto himself goes even further, arguing that "style is the man." When someone paints in the style of Rembrandt, for example, "he has adopted a manner, and to at least that degree he is not immanent in the painting in the way Rembrandt is." 42 All the same,

The language of immanence is made licit by the identity of the man himself and his style-he is his style-and by transitivity of identity Rembrandt is his paintings considered in the perspective of style. [...] What, really, is "the man himself"? I have argued a theory to the effect that we are systems of representations, ways of seeing the world, representations incarnate. ${ }^{43}$

In Leth's films of The Perfect Human, consequently, we could say that it is the human - who may be an actor or the director in the strict sense, but always a performer in the broad sense-who is these "representations incarnate", this way of seeing. And it is also a way of answering, a way of reasoning without identifiably philosophical forms of rationality. One might say that they are behavioural and cinematic explanations.

All in all, then, be it through this externalization of ideas, the behaviourist and anthropological approach adopted, or the role of the 
actor/director as a type of performer, this third version of The Perfect Human partly enacts the question of just what a remake, replica, or repetition is on a number of different levels. For the most peculiar thing is that, having been given the utmost freedom to make this version, Leth's third film is probably the least like the original when compared to the others.

\section{Crux Scenica, Or Remaking the Gesture Cinematically}

In conclusion, we should say a little more about acting and Bergson's most sustained engagement with theatrical performance and gesture-in his work, Le Rire, on laughter and the meaning of the comical. Previously, we noted that the actor playing the perfect human for the third remake in The Five Obstructions, Patrick Bauchau, was cast in part for his "well-bruised" quality. He performs the "Man in Brussels" in a set of poses mute, his worldweary face doing a good deal of the acting for him. It is notable that early cinema acting, following its theatrical forebear, was hugely influenced by the tradition of mime and gesture, with both heroic and comical postures in acting characterised as deviations from the relaxed, erect, symmetrical pose, or 'crux scenica'. David Mayer explains this in more detail as follows:

To convey such an individual, the actor's stance is the prescribed crux scenica: the relaxed body upright, arms similarly relaxed to gesture easily, knees slightly flexed, heels together, toes apart at a ninety-degree angle. This posture, which coincides with the development of ballet positions, we recognize as First Position. In any departure from a posture in which the body is always in control, denying or subduing all unruly and anti-social impulses, the actor begins to define character. Should the actor assume another stance, the audience, reading these signs, may make inferences about the character depicted. The crux scenica identified the man or woman of intellect and self-discipline. Self-control-a few key gestures and a virtual absence of multiple histrionic gestures-allowed an admirable person to survive intrigues without needing to reach for his sword or break her fan. ${ }^{4}$

In the 1830s, the Parisian elocutionist François Delsarte codified a "gestural vocabulary" for the stage. Delsarte kept to this early eighteenth-century notion that any stance that deviated from the crux scenica could be read as a sign of (bad) character. This gestural acting, while not realistic by presentday standards, was nonetheless regarded at the time as verisimilar performance. Crucially, because absolute reality was deemed unknowable, acting Truth was more highly valued than a putative acting realism. As James Naremore relates, this is what theatre historians "now call the mimetic or "pantomime" tradition-a performance technique that relies on conventionalized poses to help the actor indicate "fear," "sorrow," "hope," 
"confusion," and so forth." This was opposed to the position of "psychological realism" found in naturalism and later Method acting. ${ }^{45}$

Jean-Claude Schmitt has written about how the concept of attitude (modus habendi) is closely associated with that of figuratio. It results from the pausing of the movement that forms an ideal figure. ${ }^{46}$ Similarly, Elisabeth Engberg-Pedersen tells us that "differences in body posture link with emotionally different facial expressions to signal sequences of discourse with shifted attribution of expressive elements." 47 In many respects, then, from what we have already seen, Bergson also belongs to this tradition of physicalised attitude, only now displaced onto philosophy. When writing on attention, he showed how "stage by stage we shall be led on to define attention as an adaptation of the body rather than of the mind and to see in this attitude of consciousness mainly the consciousness of an attitude." 48 It is even arguable that this rich behaviourism of Bergson renders the problem of propositional attitudes (of beliefs) bodily, a matter of physical posture (attitudine). For as we saw, thinking itself is equally vectorised in a clearly behaviourist manner, albeit also being internalised as a tendency, "performed in the brain." Here we have the aforementioned microbehaviours of the brain alongside a macro-behaviours of bodies. Any causal reduction (of brain by world or vice versa) would not be entailed, for the macro-posture would simply be the "externalised" translation of many micro-postures, none of which are determining because each domain is equally real.

Deviations from the crux scenica, we were told, often bore the physical weight of comedy - the clownish, animal distortions of the perfectly human posture-erect and in control. The comical both imitates and distorts what is deemed the norm. In the kinds of cinematic aping that we see in The Five Obstructions, each remake repeats and distorts the original (sometimes with comical results). As Paisley Livingstone noted, some of the remakes not only mimic their original (Leth's The Perfect Human), but also create "a comical flaunting of Trier's injunction"-cocking a snook at von Trier's own attempts to "control" Leth's artistic work. Such gestural derision also resonates with Bergson's theory of comedy in Le Rire. Here, he points to the comic potential in the connection between gesture and repetition:

In a public speaker, for instance, we find that gesture vies with speech. Jealous of the latter, gesture closely dogs the speaker's thought, demanding also to act as interpreter. [...] But I find that a certain movement of head or arm, a movement always the same, seems to return at regular intervals. If I notice it and it succeeds in diverting my attention, if I wait for it to occur and it occurs when I expect it, then involuntarily I laugh. Why? Because I now have before me a machine that works automatically. 
This admonition in laughter is part of the social caution that Bergson finds operating at the heart of humour - the need to control those who deviate from life's proper function (to create, to be novel) - those who allow the mechanical to encrust itself upon the living (through habit, distraction, interference): "This is no longer life, it is automatism established in life and imitating it. It belongs to the comic." 49 Yet what is notable here is that the perception of repetition, through gesture, results in "involuntarily" laughter amongst those condemning it. The automatism is infectious.

Yet it is not only repetition, but an excess of similarity that leads to further humour. Bergson links this notion to a related problem found in Blaise Pascal's Pensées:

This seems to me the solution of the little riddle propounded by Pascal in one passage of his Thoughts: "Two faces that are alike, although neither of them excites laughter by itself, make us laugh when together, on account of their likeness." It might just as well be said: "The gestures of a public speaker, no one of which is laughable by itself, excite laughter by their repetition." The truth is that a really living life should never repeat itself. Wherever there is repetition or complete similarity, we always suspect some mechanism at work behind the living. Analyse the impression you get from two faces that are too much alike, and you will find that you are thinking of two copies cast in the same mould, or two impressions of the same seal, or two reproductions of the same negative-in a word, of some manufacturing process or other. This deflection of life towards the mechanical is here the real cause of laughter. 50

This excess of similarity creates a comical monstrosity. Hence, perhaps, one answer to the negative reception of Gus Van Sant's replica of Psycho: the excess similarity is not only a repetition of crude audio-visual structure and story, but a monstrous, mechanical one lacking in the minimal vitality that would make a remake more than simply a repeition of form, but the regeneration, or reinvention, of an idea. The Five Obstructions document how one might repeat the gestures of a short film, but doing so without this becoming a mechanical gesture-and this occurs through Leth's creative responses to von Trier's obstructions. Each remake "reinvents" - to use Bergson's term - the original, and thereby remakes not a story component or visual, but what was gestured, suggested, or directed, in the original. In true Bergsonian fashion, it is a movement-actual and bodily-rather than an ideal (Deleuzian virtual) that is realised. Van Sant takes full control his film by molding it on a fixed ideal (Hitchcock's 1960 original) and yet in doing so, only makes his work all the more mechanical-or rather, exposes his own art to the accusation of being an automatism, a predictable cliché. Even when Leth was given full "control" of the third remake, he did not revert to (his) "type" and utilise his normal long-take realist aesthetic - he invented a 
new style (itself composed of others' clichés). By reinventing them for himself, however, he removed them from being simple formulae, just as his remake on The Perfect Human are never predictable.

Bergson's philosophy was once described as "an analysis against analysis", and as such it could only suggest rather than demonstrate its truth. ${ }^{51}$ Accordingly, it is entirely true, as Bernard Gilson wrote, that each of Bergson's books was "conceived at once as a scientific work and as a work of art." 52 Writing in 1965, Paul de Man put the nature of Bergson's aesthetic in an even clearer light: "The poetic image [...] becomes a close verbal approximation to what perception and sensation are actually like, much closer, at any rate, than the purely intellectual representation of reality found in the scientific concept. Poetics thus becomes a vital source for theoretical psychology, rather than a minor part of it." 53 The poetic image is not an ornament but an aisthesis, which we see now as a matter of "attitude," of "approximation," and of "direction": an imagery that embodies (gestures) suggestion, at least when it comes to communicating an intuition to another mind. Such posturing or "posing" is a much cinematic, however, as it is philosophical.

Despite Bergson's ambivalent relationship with the cinematic apparatus (as a device of capture and projection), we need not turn to Deleuze's monstrous reading to redeem it. That rendering inflates the virtual into (unBergsonian) ontology and so pays too high a price (while also replacing a critique of capture with a commendation of editing): we can instead retain the processual and anti-Platonist dimension of Bergson's thought, and render it cinematic, but only by focusing on the important place of the actual body - of gesture, attitude, and suggestion-in Bergsonism. Indeed, it is the cinematic Bergson that exposes the postural aspect of cinema and shows how one "idea" can be remade again and again and yet also be novel - through reinvention.

1 Gilles Deleuze, Cinema 1: The Movement-Image, trans. Hugh Tomlinson and Barbara Habberjam (Minneapolis: University of Minnesota Press, 1986), 109.

${ }^{2}$ Henri Bergson, Creative Evolution, trans. Arthur Mitchell (London: Macmillan, 1911).

${ }^{3}$ Michel Georges-Michel, "Henri Bergson nous parle du cinema," Le Journal, 20 February (1914) cited in Paul Douglass, "Bergson and Cinema: Friends or Foes?," in The New Bergson, ed. John Mullarkey (Manchester: Manchester University Press, 1999), 218.

${ }^{4}$ See John Mullarkey, "Forget the Virtual: Bergson, Actualism, and the Refraction of Reality," Continental Philosophy Review 37 (2004) and John Mullarkey, Philosophy and the Moving Image (Basingstoke: Palgrave-Macmillan, 2010), 97-100 (on Deleuze's distortion of Bergson's attitude to cinema). 
${ }^{5}$ Dominique Chateau, Cinéma et philosophie (Paris: Armand Colin, 2005), 7.

6 Jean Renoir, “Conversation with Jean Renoir / 1962" with Louis Marcorelles, Jean Renoir Interviews, ed. Bert Cardullo (Jackson: University of Mississippi Press, 2005), 113.

${ }^{7}$ Henri Bergson, The Creative Mind: An Introduction to Metaphysics, trans. Mabelle L. Andison (New York: Philosophical Library, 1946), 108-9.

8 Ibid., 118.

9 Ibid., 109.

10 See Mullarkey, Philosophy and the Moving Image for more on the difference between a philosophy of film and a film of philosophy, that is, an approach that uses extant philosophy to explain film and one that sees film as generating new philosophies of its own.

${ }^{11}$ Henri Bergson, Matter and Memory, trans. Nancy Margaret Paul and W. Scott Palmer (New York: Zone Books, 1988), 135, 14; Henri Bergson, Mind-Energy: Lectures and Essays, trans. H. Wilson Carr (Westport: Greenwood Press, 1975), 53.

12 The Five Obstructions, Lars Von Trier and Leth (2003; Denmark: Zentropa/Koch Lorber Films, 2004), DVD.

${ }^{13}$ Apart from artifacts (both visual and auditory) stemming from the new contemporary setting of the story and its recasting, the most startling intentional differences come in the two murder scenes, which have surreal/subjective inserts.

${ }^{14}$ See Godfrey Cheshire, “Psycho-'Psycho’ Analysis: Van Sant's Remake Slavish but Sluggish” (1998), at http://variety.com/1998/film/reviews/psycho-psycho-analysis-van-sant-s-remake-slavishbut-sluggish-1200456298, accessed June 1, 2014 and Fontaine Lien, "Review of Psycho," in IMDB Reviews (1998), at www.imdb.com/reviews/188/18868.html, accessed June 6, 2014.

${ }^{15}$ Bergson, The Creative Mind, 177.

16 Ibid., 190.

17 Quentin Meillassoux, "Subtraction and Contraction: Deleuze, Immanence, and Matter and Memory," Collapse 3 (2007), 70-1.

18 Bergson, Matter and Memory, 21, first italics mine.

19 Ibid., 20-1.

20 Ibid., 133-4, my italics.

${ }^{21}$ Bergson, The Creative Mind, 86-7.

22 Ibid, 304 n14.

23 Ibid.

${ }^{24}$ Bergson, Mind-Energy, 56-9.

25 Giorgio Agamben, "The Six Most Beautiful Minutes in the History of Cinema," in Profanations, trans. Jeff Fort (New York: Zone Books, 2007), 93.

${ }^{26}$ Giorgio Agamben, “Notes on Gesture," in Means Without End: Notes on Politics, trans. Vincenzo Binetti and Cesare Casarino (Minneapolis: University of Minnesota Press, 2000), 55. 
27 Ibid., 56.

${ }^{28}$ Giorgio Agamben, “Author as Gesture," in Profanations, trans. Jeff Fort (New York: Zone Books, 2007), 66; Agamben, “Notes on Gesture," 58.

${ }^{29}$ Bergson, The Creative Mind, 162.

${ }^{30} \mathrm{Ibid}$.

${ }^{31}$ Mette Hjort, "Style and Creativity in The Five Obstructions," in Dekalog 01: The Five Obstructions Notes, ed. Mette Hjort (London: Wallflower Press, 2008), 33.

32 Peter Schepelern. "To Calculate the Moment: Leth's Life as Art," in Dekalog 01: The Five Obstructions Notes, ed. Mette Hjort (London: Wallflower Press, 2008), 98.

33 Murray Smith, "Funny Games," in Dekalog 01: The Five Obstructions Notes, ed. Mette Hjort (London: Wallflower Press, 2008), 130.

34 The Five Obstructions, 00:45:12 to 00:45:33.

35 The rest of these remakes are analysed-in the context of posthuman thought and François Laruelle's non-philosophy-in John Ó Maoilearca, All Thoughts Are Equal: Laruelle and Nonhuman Philosophy (Minneapolis: University of Minnesota Press, 2015).

36 Ibid., 118.

${ }^{37}$ Cited in Hjort "Style and Creativity in The Five Obstructions," 21.

$38 \mathrm{lbid}$.

39 Smith, “Funny Games," 135.

40 Paisley Livingston, "Artistic Nesting in The Five Obstructions," in Dekalog 01: The Five Obstructions Notes, ed. Mette Hjort (London: Wallflower Press, 2008), 65.

${ }^{41}$ Hjort, "Style and Creativity in The Five Obstructions," 22, 23.

42 Arthur Danto, The Transfiguration of the Commonplace: A Philosophy of Art (Cambridge: Harvard University Press, 1981), 204.

43 Ibid.

44 David Mayer, “Acting in Silent Film: Which Legacy of the Theatre?,” in Screen Acting, eds. Alan Lovell and Peter Krämer (London: Routledge, 1999), 13.

45 James Naremore, Acting in the Cinema (University of California Press, 1988), 51, 52.

46 Jean-Claude Schmitt, La Raison des gestes dans l'Occident medieval (Paris: Gallimard, 1990), 41, 177ff. My thanks to Sven Läwen for this reference.

47 Elisabeth Engberg-Pedersen, "From Pointing to Reference and Predication: Pointing Signs, Eyegaze, and Head and Body Orientation in Danish Sign Language," in Pointing: Where Language, Culture, and Cognition Meet, ed. Sotaro Kita (New Jersey: Lawrence Erlbaum, 2003), 287.

48 Bergson, Matter and Memory, 100.

49 Henri Bergson, Laughter: An Essay on the Meaning of the Comic Laughter, trans. Cloudesley Brereton and Fred Rothwell (Seattle: CreateSpace, 2011), 12. 
50 Ibid., $12-13$.

51 V. Delbos, “Matière et Mémoire: Revue Critique," cited in François Heidsieck, Henri Bergson et la notion d'Espace (Paris: Le Circle du Livre, 1957), 90.

52 Bernard Gilson, L'Individualité dans la philosophie de Bergson (Paris: Librairie Philosophique J.Vrin, 1978), 64.

53 Paul de Man, "Modern Poetics in France and Germany," in Paul de Man, Critical Writings 19531978, ed. with an introduction by Lindsay Waters (Minneapolis: University of Minnesota Press, 1989), 154. 